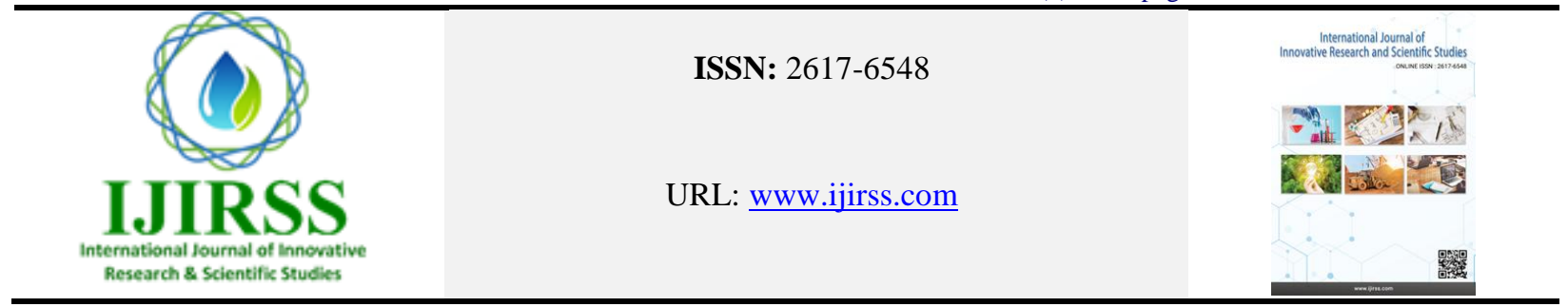

\title{
Relationship Between Internet Addictions and Academic Performance among Afghan Universities Students
}

\author{
Hassan Rahnaward Ghulami ${ }^{1 *}$, Mohd Rashid Ab Hamid² ${ }^{2}$ Mohd Reza Ibrahim ${ }^{3}$, Ali Hikmat ${ }^{4}$, Hussein Aziz ${ }^{5}$
}

\author{
${ }^{I}$ Department of Mathematics, Faculty of Natural Science, Bamyan University 1001 Bamyan, Afghanistan \\ ${ }^{2}$ Faculty of Industrial Science and Technology, Universiti Malaysia Pahang, Lebuhraya Tun Razak, 26300 Gambang, Kuantan, Pahang, \\ Malaysia. \\ ${ }^{3}$ Department of Sociology, Faculty of Social Science, Bamyan University, 1001 Bamya, Afghanistan. \\ ${ }^{4}$ Department of English, Faculty of Education, Bamyan University, 1001 Bamya, Afghanistan \\ ${ }^{5}$ Department of Physic, Faculty of Natural Sciences, Bamyan University, 1001 Bamya, Afghanistan
}

*Corresponding author: Hassan Rahnaward Ghulami (Hassan.r.gh@gmail.com)

\begin{abstract}
This study evaluates the relationship between Internet addiction and academic performance among students of eight Afghan universities. The differences between internet addiction in terms of gender was also identified. The survey/research method adopted the Internet Addiction Test (IAT) based on Young's survey applied with some modifications. From 1000 distributed questionnaires only 976 participants (358 females, and 618 males) were responded completely. The descriptive analysis was used to identify the demographic characteristics of student's Internet usage profile. The independents sample t-test was performed to determine the differences in the level of Internet addiction in terms of gender. Statistical significance was set at a value of $\mathrm{p}<0.01$. Likewise, the correlation test was implemented to identify the relationship between Internet addiction and academic performance, with referencing of sample. The results indicated that statistically there is a significant correlation among Internet addiction and academic performance. Results also indicated that statistically there were significant differences between Internet addictions in terms of demographic characteristics. This study suggests that future researchers need to work on large sample while conducting the related research. It emphasizes that students should concentrate more on their academic activities than spending time on unnecessary Internet surfing. Findings also revealed that, in Afghanistan the problem of Internet addiction is not a serious challenge, but this information should be disseminated among undergraduate university students to stop the indulgent in using the Internet.
\end{abstract}

Keywords: Internet addiction, Internet use, Academic performance, Gender.

DOI: 10.53894 /ijirss.v1i4.10

Funding: This study received no specific financial support.

History: Received: 24 October 2018/Revised: 16 November 2018/Accepted: 14 December 2018/Published: 28 December 2018

Licensed: This work is licensed under a Creative Commons Attribution 4.0 License $(\mathrm{cc}) \mathrm{Er}$

Acknowledgement: The authors thank Mr. Ahmadshah Qasimi, Omid Tajik, Javid Azimi, Shahwali Shahidi, and Abdullah Mahajer for performing the study. Also, we would like to thank Higher Education Development Program (HEDP) and Ministry of Higher Education for the provided financial supports.

Competing Interests: The authors declare that they have no conflict of interests.

Transparency: The authors confirm that the manuscript is an honest, accurate, and transparent account of the study was reported; that no vital features of the study have been omitted; and that any discrepancies from the study as planned have been explained.

Ethical: This study follows all ethical practices during writing. 


\section{Introduction}

Today, using technology and online services have become a necessity for all university students around the world [1, 2]. It's reported that the Internet use in Afghanistan began in 2002 after interim government took power in Kabul [3]. Although, in 2003, a legal control of the ".af" domain was given to Afghanistan and the Afghanistan Network Information Center (AFGNIC) was established to administer and manage domain names. Likewise, there were at least 46 Internet Services Provider (ISPs) in the country with 1 million Internet users which are stated by word Fact book in 2010. In addition, the 3G services began in 2012 and are provided by all major telecommunication companies, namely Roshan, Etisalat, MTN group, and Afghan Wireless, and it's dramatically increased by mid-2015. There were around two million $3 \mathrm{G}$ mobile broadband subscriber in the country. The current government believes that the technology of information and communication can provide opportunities for disadvantage groups and improve all the fields especially education, higher education and research. The Internet is a useful tool for communication, entertainment, research, and commerce. In Afghanistan the Internet penetration remains very low and it has significantly increased from $3 \%$ to $11 \%$ over the past five years in 2016. It is predicted that the Internet penetration to increase significantly to over $15 \%$ by 2018 in overall Afghanistan.

In recent years, the Internet in both developed and developing countries has becoming an extensive accepted channel for information exchange and networking among universities' students and in society. It is argued, that the academic use of Internet is primarily intended for research faculties and communication, but students mostly used it to communicate with friends and family members [4]. The results of several research projects showed that the major application of the Internet for college students is interpersonal communication through social networks such as instant messaging, email, and chat programs [2, 5-8]. However, it is reported by Young [9], that most of the Internet users agreed the benefit of the Internet as healthy productive activities such as students can grab the opportunity by surfing web-sites, excellent tool for the research, engaging in chat-room, and so on. On the other hand, many students fall behind in their academic performance because of excessive investments in online relationships and unnecessary use of social media which are called Internet addiction [10, 11]. Further, it is stated by $19.7 \%$ of the university students that use of their Internet had negative impact on the academic results of their previous year and ranked the Internet application in the health impediments to learning [12]. Once they fall into the temptation of the Internet, they spend most of their time using it, which finally results to pathological use in some students. Furthermore, those university students who have used the Internet addictively, they are encountered obstacles in their sleep, studies and completing their assignments as well $[13,14]$.

According to Young [9] the first time Internet addiction introduced was in 1996 by the Annual Meeting of the American Psychological Association among both academicians and clinicians. However, the definition of addiction has moved beyond this to include a number of interactive concepts, such as gambling addiction [15], video game playing [16], overdoing [17], love relationships [18], and television viewing [19]. Internet addiction is defined as, "an individual's inability to manage his or her use of the Internet, which finally results social, psychological, school, and/or work difficulties in a person's life" [20]. It is found that the university students may use the Internet addictively or Internet addiction adversely effects on individuals, physical health, family life, changing their social behavior, habits and abilities, and academic performance [6, 14, 19-23]. In spite of the facts, Internet addiction was the first classified as a behavioral addiction and characterized as a form of cyber sexual addiction [24], cyber-relationship addiction [25], net compulsion [26], information overload [27], and addiction to interactive computer games [1,28].

Recently, several studies have found a relationship between academic performance and Internet addiction among undergraduate university and schools' students [6, 19, 29-36]. According to Akhter [19] the academic problems affected by Internet addiction include missing classes [14], decline in study habits [33], significant drop in grades [23], increased risk of being placed on academic probation [29], and deprived integration in additional activities [30]. Similarly, most of the university students use social media mainly for socializing activities [37], slightly than for academic purpose [32]. Research findings have shown that Internet addicts frequently suffer from unlike emotional distress such as negative attitudes towards academic performance, anxiety, depression, boring life, and joyless [19, 21, 29, 37, 38]. On the other hand, there are some benefits of Internet access for university students. While Suissa [39], stated that Internet usage impacts learning process in a positive way by communication with lecturers and classmates, increasing access to educational databases, libraries, doing assignment, and other academic activities [19, 29]. Particularly in Afghanistan, Internet has been widely used by university students and researchers, and nowadays it is becoming a serious social problem as excessive usage of Internet, especially among undergraduate students.

The exciting literatures have reported gender differences in Internet usage [19, 23, 26, 29, 40-42]. The studies revealed that male students tend to be more familiar with the usage of Internet as compared to female students, and statistically there is a significant difference in Internet addiction among males and females [19, 23, 37, 43]. Akhter [19] reported the similar result that male students are significant predictor of Internet addiction than female students.

This study objects to investigate the three objectives:

- What is the relationship between Internet addiction and academic performance of Afghan universities students?

- What is the impact of Internet addiction on academic performance of the Afghan universities students?

- Gender differences with reference to Internet addiction.

\section{Methodology}

\subsection{Instrument}

The frequently used questionnaire for diagnoses of Internet addiction is Young's Internet Addiction Test (IAT) [2], 
which has been validated in the Korea [44], United Sates [45], United Kingdom [46], Finland [47], Taiwan [48], Spain [49], Holland [50], Hungary [51], Germany [52], Italy [53], China [54], Arabic [55], and so on. In this case, all participants were assessed using the adaptation of Persian version of the IAT.

The IAT consisted of the 20 original items which are covering the degree (minimal, moderate, and excessive Internet user) translated into Persian using translation and back translation procedure. Each item is scored on a 5-points scale ranging from (1) rarely to (5) always which are assessing different aspects of Internet use.

According to Poli and Agrimi [56] the total IAT score is followed by the score obtained by subjects in each of the six considered constructs. Table 3 shows the six IAT constructs scores as dependent variables by gender, and average of the scores obtained by single items included in each construct.

In this case, six constructs solution of Persian translated version of the IAT was used; it assesses crucial features of Internet addictions such as; first, compromised quality of social life (Mean $=2.24, \mathrm{SD}=1.28$ ); second, compromised individual quality of live (Mean $=2.31, \mathrm{SD}=1.28)$; third, compensatory use of the Internet $(\mathrm{Mean}=2.33, \mathrm{SD}=1.36$ ); fourth compromised academic/working career $($ Mean $=2.45, \mathrm{SD}=1.27$ ); fifth, compromised time control $($ Mean $=2.46$, $\mathrm{SD}=1.27$ ); and sixth, excitatory usage of the Internet (Mean $=2.36, \mathrm{SD}=1.27)[29,42,56]$. Cut-off value for the IAT were developed to divide Internet use into minimal which scores 20-39, moderate 40-59, and excessive Internet user scores 60100 [42]. The internal reliability of the scales has been the acceptable level and the Cronbach Alpha was found to be 0.88 .

\subsection{Participants}

After obtaining the formal permission from the Ministry of Higher Education and in charges of concerned universities; random sampling was used to collect data from eight public and private universities which are located in the north, west, and central of Afghanistan. Students were assured regarding the confidentiality of the data and instructions were also given about the questionnaire.

The participants' demographic information shown in Table 1. From 1000 distributed questionnaires only 976 participants $358(36.68 \%)$ females, and $618(63.32 \%)$ males were responded from: 68 (6.9\%) Bamyan University, 255 (26.13\%) Kabul University, 167 (17.12\%) Shaid-Rabani University, 112 (11.47\%) Takhar University, 138 (14.14\%) Hirat University, 68 (6.96\%) Bamika University, 48 (5.03\%) Ghargistan University, and 119 (12.19\%) Jawzjan University. The sample had a mean age of $($ mean $=21.68, \mathrm{SD}=3.17$, range 18-34) years. All respondents were undergraduate students: 364 (37.30\%) natural science, 198 (20.29\%) engineering, 414 (42.41\%) and art and social science. Average time taken in filling questionnaire was 20 minutes.

Participants were reported that: 657(67.31\%) spending between 1-3 hours per day online for social media (Facebook, Instagram, WhatsApp, Twitter, and etc.); 230 (23.56\%) spending 4-7 hours per day online for entertainment (films, TV, game, music, and etc.); and 89 (9.31\%) spending over 7 hours per day online for education searching (e-book, journal paper, proceeding paper, lecture note, and etc.).

Academic performance of the undergraduate students was measured with Grade Point of Average (GPA) was obtained from the departments of students' affairs of mentioned universities.

\subsection{Analysis}

The participants' Internet usage profile and the level of Internet addiction were presented using descriptive analysis by SPSS version 22. In addition, to descriptive analysis, inferential statistics was also conducted to examine the hypothesis of the current study.

The independents sample t-test was performed to evaluate the differences in the level of Internet addiction in terms of gender. Statistical significance was set at $p<0.01$. Likewise, the correlation test was implemented to identify the relationship between Internet addiction and academic performance with referencing of sample.

\section{Results and Findings}

The prevalence rate of Internet addiction is shown in Table 2. In this case, according to the IAT [9, 42]: 186 (19.06\%) students $(20.87 \%$ male, $15.92 \%$ female) were excessive Internet user which are considered high addicted; $461(47.23 \%)$ students $(51.94 \%$ male, $39.11 \%$ female) were moderate Internet users; and $329(33.71 \%)$ students $(27.18 \%$ male, $44.97 \%$ female) were minimal Internet users.

Generally, the finding of the study indicated that Afghan undergraduate university students have moderate Internet addiction. In addition, the results of the current study also showed that male students are more addicted than female students, and female students mostly use Internet for academic purposes, while male students use Internet for nonacademic purposes. 
Table-1.

Participants' demographic characteristics by gender

\begin{tabular}{|c|c|c|c|c|}
\hline \multicolumn{2}{|l|}{ Factors } & $\begin{array}{l}\text { Total }(\mathrm{n}=976) \\
N(\%)\end{array}$ & $\begin{array}{l}\text { Males }(\mathrm{n}=618) \\
N(\%)\end{array}$ & $\begin{array}{l}\text { Females } \\
(\mathrm{n}=358) \\
N(\%)\end{array}$ \\
\hline \multirow[t]{5}{*}{ Age (Years) } & $18-22$ & $704(72.13)$ & $400(64.72)$ & $304(84.92)$ \\
\hline & $23-26$ & $211(21.62)$ & $173(27.99)$ & $38(10.61)$ \\
\hline & $27-30$ & $31(3.18)$ & $24(3.88)$ & $7(1.96)$ \\
\hline & $31-34$ & $18(1.84)$ & $14(2.27)$ & $4(1.12)$ \\
\hline & More than 34 & $12(1.23)$ & $7(1.13)$ & $5(1.40)$ \\
\hline \multicolumn{2}{|l|}{ Mean (SD) } & $21.68(3.17)$ & $22.35(2.62)$ & $21(1.72)$ \\
\hline \multicolumn{2}{|l|}{ Median } & 21 & 20 & 19 \\
\hline \multicolumn{2}{|l|}{ Mode } & 20 & 20 & 20 \\
\hline \multirow[t]{6}{*}{ GPA } & $100-90$ & $101(10.35)$ & $45(7.28)$ & $56(15.64)$ \\
\hline & $89-80$ & $275(28.18)$ & $160(25.89)$ & $115(32.12)$ \\
\hline & $79-70$ & $398(40.78)$ & $280(45.31)$ & $118(32.96)$ \\
\hline & $69-60$ & $144(14.75)$ & $97(15.70)$ & $47(13.13)$ \\
\hline & $69-55$ & $52(5.33)$ & $32(5.18)$ & $20(5.59)$ \\
\hline & Less than 55 & $6(0.61)$ & $4(0.65)$ & $2(0.56)$ \\
\hline Mean (SD) & & $76.78(10.30)$ & $75.50(9.74)$ & $78.30(11.01)$ \\
\hline Median & & 73 & 74 & 71 \\
\hline Mode & & 73 & 74 & 70 \\
\hline \multirow[t]{8}{*}{ Universities } & Bamyan University & $68(6.96)$ & $42(6.80)$ & $26(7.26$ \\
\hline & Kabul University & $255(26.13)$ & $177(28.64)$ & $78(21.79)$ \\
\hline & Shaheed-Rabbani University & $167(17.12)$ & $107(17.31)$ & $60(16.76$ \\
\hline & Takhar University & $112(11.47)$ & $98(15.86)$ & $14(3.9)$ \\
\hline & Herat University & $138(14.14)$ & $30(4.85)$ & $108(30.17)$ \\
\hline & Bamika University & $68(6.96)$ & $62(10.03)$ & $6(1.68)$ \\
\hline & Gharjistan University & $49(5.03)$ & $26(4.21)$ & $23(6.42)$ \\
\hline & Jawzjan University & $119(12.19)$ & $76(12.30)$ & $43(12.01$ \\
\hline \multirow[t]{3}{*}{ Discipline Studied } & Natural Science & $364(37.30)$ & $214(34.63)$ & \\
\hline & Engineering & $198(20.29)$ & $151(24.43)$ & \\
\hline & Art \& Social Science & $414(42.42)$ & $253(40.94)$ & \\
\hline
\end{tabular}

$* \mathrm{SD}=$ standard deviation

Table-2.

Internet addiction level

Addicted Level

High Addicted (60-100)

Moderate Addicted (40-59)

Low Addicted (20-39)

\begin{tabular}{|l|c|c|} 
& Total N (\%) & \\
\hline 00$)$ & $186(19.06)$ & \\
\hline $40-59)$ & $461(47.23)$ & \\
\hline ) & $329(33.71)$ & \\
\hline
\end{tabular}

\begin{tabular}{c} 
Males N (\%) \\
$129(20.87)$ \\
\hline $321(51.94)$ \\
$168(27.18)$
\end{tabular}

\begin{tabular}{c|c}
\hline Females N (\%) \\
\hline $57(15.92)$ \\
\hline $140(39.11)$ \\
\hline $161(44.97)$
\end{tabular}

Table-3.

Mean scores obtained by Persian version $(n=976)$ in the total ITA items and in the six ITA constructs, calculated by averaging the scores obtained by constructs in each of the considered items

\begin{tabular}{l|c|c|c}
\hline \multirow{2}{*}{ Items } & \multicolumn{2}{|c}{ Gender } \\
\cline { 3 - 4 } & $\begin{array}{c}\text { Total } \\
\text { Mean (SD) }\end{array}$ & $\begin{array}{c}\text { Male } \\
\text { Mean (SD) }\end{array}$ & $\begin{array}{c}\text { Female } \\
\text { Mean (SD) }\end{array}$ \\
\hline Compromised social quality of life & $\mathbf{2 . 2 4 ( 1 . 2 8 )}$ & $\mathbf{2 . 3 5}(\mathbf{1 . 2 8})$ & $\mathbf{2 . 1 3 ( 1 . 2 9 )}$ \\
\hline $\begin{array}{l}\text { How often do you form new relationships with fellow on-line } \\
\text { users? }\end{array}$ & $2.14(1.17)$ & $2.34(1.22)$ & $1.94(1.13)$ \\
\hline $\begin{array}{l}\text { How often do others in your life complain to you about the } \\
\text { amount of time you spend on-line? }\end{array}$ & $2.31(1.31)$ & $2.29(1.28)$ & $2.33(1.35)$ \\
\hline $\begin{array}{l}\text { How often do you become defensive or secretive when anyone } \\
\text { asks you what you do on-line? }\end{array}$ & $2.19(1.28)$ & $2.33(1.31)$ & $2.05(1.32)$ \\
\hline $\begin{array}{l}\text { How often do you snap, yell, or act annoyed if someone bothers } \\
\text { you while you are on-line? }\end{array}$ & $2.04(1.25)$ & $2.09(1.24)$ & $1.98(1.27)$ \\
\hline $\begin{array}{l}\text { How often do you find yourself saying just a few more minutes } \\
\text { when on-line? }\end{array}$ & $2.50(1.33)$ & $2.66(1.32)$ & $2.33(1.35)$ \\
\hline How often do you try to hide how long you've been on-line? & $2.28(1.31)$ & $2.40(1.31)$ & $2.17(1.32)$ \\
\hline Compromised individual quality of life & $\mathbf{2 . 2 6 ( 1 . 2 8 )}$ & $\mathbf{2 . 5 1 ( 1 . 2 9 )}$ & $\mathbf{2 . 1}(\mathbf{1 . 2 7})$ \\
\hline
\end{tabular}




\begin{tabular}{l|c|c|c}
\hline $\begin{array}{l}\text { How often do you neglect household chores to spend more time } \\
\text { on-line? }\end{array}$ & $2.34(1.12)$ & $2.70(1.10)$ & $1.98(1.15)$ \\
\hline $\begin{array}{l}\text { How often do you fear that life without the Internet would be } \\
\text { boring, empty, and joyless? }\end{array}$ & $2.10(1.30)$ & $2.21(1.28)$ & $2.02(1.32)$ \\
\hline How often do you lose sleep due to late-night logins? & $2.48(1.28)$ & $2.70(1.29)$ & $2.25(1.27)$ \\
\hline $\begin{array}{l}\text { How often do you choose to spend more time on-line over } \\
\text { going out with others? }\end{array}$ & $2.27(1.31)$ & $2.47(1.34)$ & $2.07(1.28)$ \\
\hline $\begin{array}{l}\text { How often do you feel depressed, moody, or nervous when you } \\
\text { are off-line, which goes away once you are back on-line? }\end{array}$ & $2.33(1.40)$ & $2.50(1.42)$ & $2.16(1.38)$ \\
\hline Compensatory usage of the Internet & $\mathbf{2 . 3 3 ( 1 . 3 6 )}$ & $\mathbf{2 . 4 5 ( 1 . 2 7 )}$ & $\mathbf{2 . 2 2 ( 1 . 4 5 )}$ \\
\hline $\begin{array}{l}\text { How often do you check your e-mail before something else that } \\
\text { you need to do? }\end{array}$ & $2.12(1.25)$ & $2.17(1.25)$ & $2.08(1.26)$ \\
\hline $\begin{array}{l}\text { How often do you find yourself anticipating when you will go } \\
\text { on-line again? }\end{array}$ & $2.43(1.26)$ & $2.54(1.26)$ & $2.33(1.26)$ \\
\hline $\begin{array}{l}\text { How often do you feel preoccupied with the Internet when off- } \\
\text { line, or fantasize about being on-line? }\end{array}$ & $2.45(1.56)$ & $2.65(1.29)$ & $2.26(1.83)$ \\
\hline Compromised academic and careers & $\mathbf{2 . 4 5 ( 1 . 2 7 )}$ & $\mathbf{2 . 5 6 ( 1 . 2 7 )}$ & $\mathbf{2 . 3 4 ~ 1 . 2 7}$ \\
\hline $\begin{array}{l}\text { How often do your grades or schoolwork suffer because of the } \\
\text { amount of time you spend on-line? }\end{array}$ & $2.51(1.30)$ & $2.62(1.30)$ & $2.41(1.31)$ \\
\hline $\begin{array}{l}\text { How often does your job performance or productivity suffer } \\
\text { because of the Internet? }\end{array}$ & $2.37(1.23)$ & $2.49(1.24)$ & $2.26(1.22)$ \\
\hline Compromised time control & $\mathbf{2 . 4 7 ( 1 . 2 7 )}$ & $\mathbf{2 . 5 8 ( 1 . 2 6 )}$ & $\mathbf{2 . 3 5 ( 1 . 2 8 )}$ \\
\hline $\begin{array}{l}\text { How often do you find that you stay on-line longer than you } \\
\text { intended? }\end{array}$ & $2.28(1.15)$ & $2.35(1.11)$ & $2.22(1.19)$ \\
\hline $\begin{array}{l}\text { How often do you try to cut down the amount of time you } \\
\text { spend on-line and fail? }\end{array}$ & $2.64(1.35)$ & $2.81(1.34)$ & $2.48(1.36)$ \\
\hline Excitatory usage of the Internet & $\mathbf{2 . 3 6 ( 1 . 2 7 )}$ & $\mathbf{2 . 3 9 ( 1 . 2 6 )}$ & $\mathbf{2 . 3 3 ( 1 . 2 8 )}$ \\
\hline $\begin{array}{l}\text { How often do you prefer the excitement of the Internet to } \\
\text { intimacy with your partner? }\end{array}$ & $2.19(1.25)$ & $2.21(1.25)$ & $2.17(1.26)$ \\
\hline $\begin{array}{l}\text { How often do you block out disturbing thoughts about your life } \\
\text { with soothing thoughts of the Internet? }\end{array}$ & $2.52(1.28)$ & $2.56(1.26)$ & $2.48(1.30)$ \\
\hline
\end{tabular}

To meet the mentioned objectives, the following hypothesis $(\mathrm{H})$ were formulated.

H1: statistically, there is no significant relationship between Internet addiction and academic performance, with references of the sample. Table 4 presents the descriptive and correlation between Internet addiction and academic performance. The findings of the study suggested that Internet addiction had a significant impact on academic performance $(r=0.123, p<0.01)$.

Table-4.

Means, standard deviations and correlation among GPA and IA

\begin{tabular}{l|l|l|l|l}
\hline Variables & Mean & SD & $\boldsymbol{\alpha}$ & GPA \\
\hline GPA & 74.50 & 4.32 & & \\
\hline $\begin{array}{l}\text { Internet } \\
\text { Addiction }\end{array}$ & 46.80 & 14.25 & 0.88 & $0.123^{* *}$ \\
**. Correlation is significant at the 0.01 level (2-tailed) & & \\
\cline { 2 - 5 }
\end{tabular}

H2: Gender has negative impact on Internet addiction among Afghan universities students. Table 5 presents the results of the simple linear regression analysis which are calculated to find out the impact of gender on Internet addiction. In this case, sex was imitation coded as 1 and 2 in order to run the regression analysis. The result revealed that gender is also a significant factor of Internet addiction. Overall, results stated that male gender is a significant predictor of Internet addiction of the students based $(\beta=-0.15, \mathrm{t}=-4.79, \mathrm{p}<0.01)$. A significant regression equation was found $(\mathrm{F}(1,976)$ $=22.96, \mathrm{p}<0.01$, with an R2 of 0.02).

Table-5.

Impact of gender on Internet addiction

\begin{tabular}{l|c|c|c|c|c}
\hline Model & $\boldsymbol{B}$ & $\boldsymbol{S} \boldsymbol{E}$ & $\boldsymbol{\beta}$ & $\boldsymbol{t}$ & $\boldsymbol{p}$ \\
\hline Constant & 1.61 & 0.05 & & 30.66 & \\
\hline $\begin{array}{l}\text { Internet } \\
\text { Addiction }\end{array}$ & -0.10 & 0.02 & -0.15 & -4.79 & 0.01 \\
\hline
\end{tabular}

H3: Based on statistic values there is a significant difference in Internet addiction between male and female students. Table 6 describes the independent t-test which indicates that statistically there is a significant variation in Internet addiction 
among males and females based on $(t=4.80, \mathrm{p}<0.01)$, as well as it indicates the computed addicted level of the gender differences on the Internet addiction. Results showed that male students (Means $=48.45, \mathrm{SD}=13.68$ ) tend to score higher on Internet addiction than female students (Means $=43.96, \mathrm{SD}=15.2$ ).

Table-6.

Internet addiction differences among male and female

\begin{tabular}{|c|c|c|c|c|c|c|c|c|c|c|}
\hline \multirow{2}{*}{\multicolumn{2}{|c|}{$\begin{array}{l}\text { Addicted Level } \\
\text { High Addicted }\end{array}$}} & \multirow{2}{*}{$\begin{array}{c}\begin{array}{c}\text { Male } \\
(\mathbf{N}=618)\end{array} \\
\text { Mean (SD) } \\
67.28(7.28)\end{array}$} & \multirow{2}{*}{$\begin{array}{c}\begin{array}{c}\text { Females } \\
(\mathbf{N}=\mathbf{3 5 8}) \\
\text { Mean (SD) }\end{array} \\
70.32 \\
(9.63)\end{array}$} & \multirow[t]{2}{*}{$\mathbf{F}$} & \multirow[t]{2}{*}{ Sig. } & \multirow[t]{2}{*}{$\mathbf{t}$} & \multirow[t]{2}{*}{ df } & \multirow[t]{2}{*}{$\begin{array}{c}\text { Mean } \\
\text { Difference }\end{array}$} & \multicolumn{2}{|c|}{$\begin{array}{c}95 \% \\
\text { Confidence } \\
\text { Interval of } \\
\text { the } \\
\text { Difference }\end{array}$} \\
\hline & & & & & & & & & & \\
\hline \multicolumn{2}{|c|}{ Moderate Addicted } & $48.93(5.53)$ & $\begin{array}{l}48.56 \\
(5.39) \\
\end{array}$ & & & & & & & \\
\hline \multicolumn{2}{|c|}{ Low Addicted } & $32.81(4.68)$ & $\begin{array}{l}30.61 \\
(5.26)\end{array}$ & & & & & & & \\
\hline \multirow{2}{*}{$\begin{array}{l}\text { Internet } \\
\text { Addiction }\end{array}$} & $\begin{array}{l}\text { Equal } \\
\text { variances } \\
\text { assumed. }\end{array}$ & $\begin{array}{c}48.45 \\
(13.28)\end{array}$ & $\begin{array}{l}43.96 \\
(15.42)\end{array}$ & 9.56 & 0.01 & 4.80 & 975 & 4.49 & 2.65 & 6.33 \\
\hline & $\begin{array}{l}\text { Equal } \\
\text { variances } \\
\text { not } \\
\text { assumed. }\end{array}$ & & & & & 4.61 & 659 & 4.49 & 2.58 & 6.40 \\
\hline
\end{tabular}

\section{Discussion and Conclusions}

In this case, the main objective of the current study was to investigate the relationship between Internet addiction and academic performance among Afghan universities students at undergraduate level. Table 4 presented the IAT questionnaire' alpha coefficient 0.88 and achieved high reliability coefficients. The analysis performed on the IAT total score, mean and standard deviation, however the results revealed that there are differences between subjects of different gender, age, GPA and disciplines of study.

The current study developed three hypotheses to investigate the relationship between Internet addiction and academic performance. On the basis of existing empirical studies, it was hypothesized that statistically there is no significant relationship between Internet addiction and academic performance, with reference of the sample. Concerning the first hypothesis, the results revealed that Internet addiction had significantly affected the academic performance, although the academic performance is the most important predictor of Internet addiction. Same result has been indicated by other empirical studies $[9,19,23,40,57,58]$. Although, the existing literatures showing that Internet can distract students from their academic performance and lose his/her capacity to concentrate their academic activates [19, 23, 29].

Based on the second and third hypotheses of the current study, it involved in the significant differences of Internet addiction with gender, and GPA. Regarding to the profile of the Internet users, the male students are addicted more than female students. The same results were revealed by the studies of Akhter [19]; Sachitra [23]; Akın [29]; Cao and Su [40]; Weinstein and Lejoyeux [52]; $\mathrm{Ni}$, et al. [54]. Although, findings stated that male gender is a significant predictor of Internet addiction of the students which is consistent with the findings of Sachitra [23]; Gencer and Koc [33]. In conclusion, male students use Internet for nonacademic purposes, while female students use Internet for academic purposes.

Finally, according to the finding of the current study, researchers suggest some academic implications for Ministry of higher education, students and universities. The results revealed that Internet addiction had significant negative impact on academic performance of Afghan universities students. Thus, students should concentrate and concern more on their academic activities than spending unnecessary time on the Internet. Ministry of higher education, authorities, and university lecturers would have responsibility to make students aware regarding negative impact of Internet addiction on their academic performance. The authorities of university would encourage that students are engaging with more academic activities such as seminar, workshops, field visits, group assignments, sport, narrative, poetry, and so forth. If students attending the mentioned academic activities, they may not spend time on unnecessary Internet use. On the other hand, more academic involvement encourages students spend time on Internet for academic purposes.

\section{Limitations of study}

The current study was encountered with some preclusions. Initially, the sample was selected from eight universities; generalization of the findings to the total population of Afghan universities students is limited. Then, in this case only the relationship between Internet addiction and academic performance of the students investigated, but there are other variables like economical, and behavioral construct that will be affect academic performance. Thirdly, in this case only quantitative method has been used, so it is recommended to use both qualitative and quantitative method in the future studies. 
To sum up, in Afghanistan the problem of Internet addiction is not a serious challenge, but this should be noticed to stop the growing of Internet addiction among students in school and university.

\section{References}

[1] M. Seo, H. S. Kang, and Y.-H. Yom, "Internet addiction and interpersonal problems in Korean adolescents," CIN: Computers, Informatics, Nursing, vol. 27, pp. 226-233, 2009. Available at: https://doi.org/10.1097/ncn.0b013e3181a91b3f.

[Q] K. S. Young, "Internet addiction: The emergence of a new clinical disorder," Cyberpsychology Behav, vol. 1, pp. 237-244, 1998. Available at: https://doi.org/10.1089/cpb.1998.1.237.

[3] Afghanistan - Telecoms, "Mobile and broadband - statistics and analyses - Budde Comm," n.d.

[4] C. Chou, L. Condron, and J. C. Belland, "A review of the research on Internet addiction," Educational Psychology Review, vol. 17, pp. 363-388, 2005.

K. Hampton and B. Wellman, "Long distance community in the network society: Contact and support beyond Netville," American Behavioral Scientist, vol. 45, pp. 476-495, 2001. Available at: https://doi.org/10.1 177/00027640121957303.

U. N. Hayati, M. Alavi, and S. M. Shafeq, "Relationship between internet addiction and academic performance among foreign undergraduate students," Procedia-Social and Behavioral Sciences, vol. 114, pp. 845-851, 2014. Available at: https://doi.org/10.1016/j.sbspro.2013.12.795.

B. Wellman, A. Q. Haase, J. Witte, and K. Hampton, "Does the Internet increase, decrease, or supplement social capital? Social networks, participation, and community commitment," American Behavioral Scientist, vol. 45, pp. 436-455, 2001. Available at: https://doi.org/10.1177/00027640121957286.

[8] K. S. Young, "Internet addiction: symptoms, evaluation and treatment," Innovations in Clinical Practice: A Source Book, vol. 17, pp. 351-352, 1999.

[9] K. S. Young, "Internet addiction: A new clinical phenomenon and its consequences," American Behavioral Scientist, vol. 48, pp. 402-415, 2004. Available at: https://doi.org/10.1177/0002764204270278.

[10] M. T. Hansen, "Knowledge networks: Explaining effective knowledge sharing in multiunit companies," Organization Science, vol. 13, pp. 232-248, 2002. Available at: https://doi.org/10.1287/orsc.13.3.232.2771.

[11] A. Usman and S. H. Shami, "Evolution of communication technologies for smart grid applications," Renerwable and Sustainable Energy Reviews, vol. 19, pp. 191-199, 2013.

[12] A. C. H. Association, "American college health association-national college health assessment Spring 2008 Reference Group Data Report (abridged): The American College Health Association," Journal of American College Health, vol. 57, p. 477, 2009.

[13] M. J. Anderson, "A new method for non-parametric multivariate analysis of variance," Austral Ecology, vol. 26, pp. 32-46, 2001. Available at: https://doi.org/10.1111/j.1442-9993.2001.01070.pp.x.

[14] K. Nalwa and A. P. Anand, "Internet addiction in students: A cause of concern," Cyberpsychology छ Behavior, vol. 6, pp. 653656, 2003.

[15] D. A. Gentile, J. A. Maier, M. R. Hasson, and B. L. de Bonetti, "Parents' evaluation of media ratings a decade after the television ratings were introduced," Pediatrics, vol. 128, pp. 36-44, 2011. Available at: https://doi.org/10.1542/peds.20103026d.

[16] A. Apostolopoulos and M. Karavis, "Overeating: Treatment of obesity and anxiety by auricular acupuncture, an analysis of 800 cases," Acupuncture in Medicine, vol. 14, pp. 116-120, 1996.

[17] R. J. Hancox, B. J. Milne, and R. Poulton, "Association between child and adolescent television viewing and adult health: A longitudinal birth cohort study," The Lancet, vol. 364, pp. 257-262, 2004. Available at: https://doi.org/10.1016/s01406736(04)16675-0.

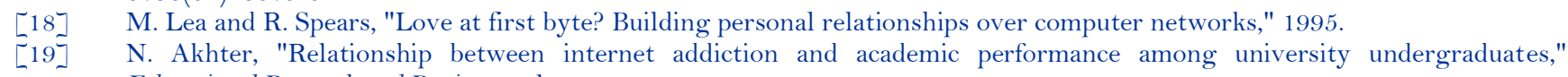
Educational Research and Reviews, vol. 8, pp. 1793-1796, 2013.

[20] R. E. Kraut, S. R. Fussell, S. E. Brennan, and J. Siegel, "Understanding effects of proximity on collaboration: Implications for technologies to support remote collaborative work," Distributed work, pp. 137-162, 2002.

[21] R. W. Kubey, M. J. Lavin, and J. R. Barrows, "Internet use and collegiate academic performance decrements: Early findings," Journal of Communication, vol. 51, pp. 366-382, 2001. Available at: https://doi.org/10.1111/j.1460-2466.2001.tb02885.x.

[22] W. Kubey, P. Straka, and C. Holmes, "An in vitro bacterial touch contamination risk assessment of two CAPD twinbag systems," Blood Purification, vol. 19, pp. 62-67, 2001. Available at: https://doi.org/10.1159/000014480.

[23] K. M. V. Sachitra, Internet addiction: Academic Performance and University Students, 2016.

[24] A. Cooper, "Sexuality and the internet: Surfing into the new millennium," Cyberpsychology \& behavior, vol. 1, pp. 187-193, 1998.

[25] K. Young, M. Pistner, J. O'MARA, and J. Buchanan, "Cyber disorders: The mental health concern for the new millennium," Cyberpsychology \& Behavior, vol. 2, pp. 475-479, 1999. Available at: https://doi.org/10.1089/cpb.1999.2.475.

[26] Ş. Kesici and İ. Şahin, "A comparative study of uses of the internet among college students with and without internet addiction," Psychological Reports, vol. 105, pp. 1103-1112, 2009. Available at: https://doi.org/10.2466/pro.105.f.1103-1112

[27] Y.-C. Chen, R.-A. Shang, and C.-Y. Kao, "The effects of information overload on consumers' subjective state towards buying decision in the internet shopping environment," Electronic Commerce Research and Applications, vol. 8, pp. 48-58, 2009. Available at: https://doi.org/10.1016/j.elerap.2008.09.001.

[28] I. Goldberg, "Internet addiction disorder," vol. 152004.

[29] A. Akın, "The relationships between Internet addiction, subjective vitality, and subjective happiness," Cyberpsychology, Behavior, and Social Networking, vol. 15, pp. 404-410, 2012. Available at: https://doi.org/10.1089/cyber.2011.0609.

[30] K. J. Anderson, "Internet use among college students: An exploratory study," Journal of American College Health, vol. 50, pp. 21-26, 2001 . Available at: https://doi.org/10.1080/07448480109595707.

[31] G. Andrea, D. Frédéric, K. Marie-Emmanuelle, K. Guillaume, C. Caroline, D. Moustapha, and G. Sébastien, "Evaluation of addiction among students in first year of a French University," Open Journal of Preventive Medicine, vol. 6, pp. 42-56, 2016. Available at: https://doi.org/10.4236/ojpm.2016.61004.

[32] E. S. Asemah, R. A. Okpanachi, and L. Edegoh, "Influence of social media on the academic performance of the undergraduate students of Kogi State University, Anyigba, Nigeria," Research on Humanities and Social Sciences Vol, vol. 3, 2013. 
[33] S. L. Gencer and M. Koc, "Internet abuse among teenagers and its relations to internet usage patterns and demographics," Journal of Educational Technology \& Society, vol. 15, pp. 25-36, 2012.

[34] N. Oye, A. M. Helou, and Z. Z. A. Rahim, "Students perception on social networking sites influence on academic performance," Doctoral Dissertation, Universiti Teknologi Malaysia, 2012.

[35] P. Panayides and M. J. Walker, "Evaluation of the psychometric properties of the Internet Addiction Test (IAT) in a sample of Cypriot high school students: The Rasch measurement perspective," European Journal of Psychology of Education, vol. 8, p. 327, 2012.

[36] T. Yildirim and O. Ozturk, "Evaluation of psychometric properties of the internet addiction scale in a sample of Turkish High School Students," 2010.

[37] S.-Y. Chen and Y.-C. Fu, "Internet use and academic achievement: Gender differences in early adolescence," Adolescence, vol. 44, 2009.

[38] A. Akin and M. Iskender, "Internet addiction and depression, anxiety and stress," International Online Journal of Educational Sciences, vol. 3, pp. 138-148, 2011.

[39] A. J. Suissa, "Gambling and cyber-addiction as a social problem: Some Psychosocial Benchmarks," Canadian Social Work Revier, pp. 83-100, 2013.

[40] F. Cao and L. Su, "Internet addiction among Chinese adolescents: Prevalence and psychological features," Child: Care, Health and Development, vol. 33, pp. 275-281, 2007. Available at: https://doi.org/10.1111/j.1365-2214.2006.00715.x.

[41] C. Chou, "Internet heavy use and addiction among Taiwanese college students: An online interview study," Cyberpsychology $\&^{\circ}$ Behavior, vol. 4, pp. 573-585, 2001 . Available at: https://doi.org/10.1089/109493101753235160.

[42] G. Scimeca, A. Bruno, L. Cava, G. Pandolfo, M. R. A. Muscatello, and R. Zoccali, "The relationship between alexithymia, anxiety, depression, and internet addiction severity in a sample of Italian high school students," The Scientific World Journal, vol. 2014, 2014.

[43] E. B. Weiser, "Gender differences in Internet use patterns and Internet application preferences: A two-sample comparison," Cyberpsychology and Behavior, vol. 3, pp. 167-178, 2000. Available at: https://doi.org/10.1089/109493100316012.

[44] D. Hyun, Y. Sik, C. Na, J. Young, U. Sun, M. A. Daniels, C. A. Haws, and P. F. Renshaw, "The effect of methylphenidate on Internet video game play in children with attention-deficit / hyperactivity disorder," Psychiatry, vol. 50, pp. 251-256, 2009.

[45] S. Bernardi and S. Pallanti, "Internet addiction: a descriptive clinical study focusing on comorbidities and dissociative symptoms," Psychiatry, vol. 50, pp. 510-516, 2009.

[46] L. Widyanto and M. McMurran, "The psychometric properties of the internet addiction test," Cyberpsychology छ Behavior, vol. 7, pp. 443-450, 2004. Available at: https://doi.org/10.1089/cpb.2004.7.443.

[47] J. Korkeila, S. Kaarlas, M. Jääskeläinen, T. Vahlberg, and T. Taiminen, "Attached to the web-harmful use of the Internet and its correlates," European Psychiatry, vol. 25, pp. 236-241, 2010. Available at: https://doi.org/10.1016/j.eurpsy.2009.02.008.

[48] C. F. Yen, C. H. Ko, J. Y. Yen, Y. P. Chang, and C. P. Cheng, "Multi-dimensional discriminative factors for Internet addiction among adolescents regarding gender and age," Psychiatry and Clinical Neurosciences, vol. 63, pp. 357-364, 2009. Available at: https://doi.org/10.1111/j.1440-1819.2009.01969.x.

[49] F. M. Beranuy, A. C. Lusar, C. G. Jordania, and X. C. Sánchez, "Validation of two brief scales for Internet addiction and mobile phone problem use," Psicothema, vol. 21, pp. 480-485, 2009.

[50] G.-J. Meerkerk, R. J. Van Den Eijnden, A. A. Vermulst, and H. F. Garretsen, "The compulsive internet use scale (CIUS): some psychometric properties," Cyberpsychology \& Behavior, vol. 12, pp. 1-6, 2009. Available at: https://doi.org/10.1089/cpb.2008.0181.

[51] Z. Demetrovics, B. Szeredi, and S. Rózsa, "The three-factor model of Internet addiction: The development of the Problematic Internet Use Questionnaire," Behavior Research Methods, vol. 40, pp. 563-574, 2008. Available at: https://doi.org/10.3758/brm.40.2.563.

[52] A. Weinstein and M. Lejoyeux, "Internet addiction or excessive internet use," The American Journal of Drug and Alcohol Abuse, vol. 36, pp. 277-283, 2010.

[53] S. Pallanti, S. Bernardi, and L. Quercioli, "The Shorter PROMIS Questionnaire and the Internet Addiction Scale in the assessment of multiple addictions in a high-school population: prevalence and related disability," CNS Spectrums, vol. 11, pp. 966-974, 2006. Available at: https://doi.org/10.1017/s1092852900015157.

[54] X. Ni, H. Yan, S. Chen, and Z. Liu, "Factors influencing internet addiction in a sample of freshmen university students in China," Cyberpsychology \& Behavior, vol. 12, pp. 327-330, 2009. Available at: https://doi.org/10.1089/cpb.2008.0321.

[55] N. S. Hawi, "Arabic validation of the Internet addiction test," Cyberpsychology, Behavior, and Social Networking, vol. 16, pp. 200204, 2013. Available at: https://doi.org/10.1089/cyber.2012.0426.

[56] R. Poli and E. Agrimi, "Internet addiction disorder: Prevalence in an Italian student population," Nordic Journal of Psychiatry, vol. 66, pp. 55-59, 2012.

[57] Y. Khazaal, J. Billieux, G. Thorens, R. Khan, Y. Louati, E. Scarlatti, F. Theintz, J. Lederrey, M. Van Der Linden, and D. Zullino, "French validation of the internet addiction test," Cyberpsychology \& Behavior, vol. 11, pp. 703-706, 2008.

[58] A. S. Hall and J. Parsons, "Internet addiction: College student case study using best practices in cognitive behavior therapy," Journal of Mental Health Counseling, vol. 23, p. 312, 2001. 